\title{
Narrative tolerance: on the road to unbiased history, cultural tolerance and civil society
}

\author{
Olena Mishalova ${ }^{1,2, *}$ \\ ${ }^{1}$ Nanjing Normal University, Philosophy Department, Nanjing, 210000, China \\ ${ }^{2}$ Kryvyi Rih State Pedagogical University, Philosophy Department, Kryvyi Rih, 50086, Ukraine
}

\begin{abstract}
The article examines a concept of narrative tolerance as the basic structure of cultural tolerance and modern civil society. It is proposed to consider narrative tolerance as an effective methodological tool to create a tolerant inclusive sociocultural world paradigm. The tolerant sociocultural approach in history studying and teaching is a crucially important condition that makes it possible to resolve protracted historical conflicts both within and beyond countries and, as a result, leads to reconciliation and mutual forgiveness.
\end{abstract}

\section{The notion of narrative tolerance}

The modern information society is an open society. This circumstance makes it extremely vulnerable for manipulation of public consciousness, especially when it concerns the problematic issues of the past. Every careless word about the past can cause public outcry inside the country, provoke an inter-state conflict or cause the renewal of an old conflict which does not exist any more in reality, that belongs to the past, but it still continues to exist in the historical space (so-called "wars of historical narratives"). A striking example of the latter is the uneasy history of Ukrainian-Polish relations in the middle of the last century ("Volyn massacre", the operation "Wisla"), which was full of mutual aggression, and which remains very problematic up to nowadays and requires attention of both historians and philosophers of history.

It should be emphasized that every country in the modern world has similar problematic historical pages in its history. As an example, we can take the history of the United States. Ukraine and the United States have much in common: both countries have a complicated history of struggle for their independence, both of which are multinational, multicultural and multireligious. This similarity is also reflected in the similarity of sociopolitical issues facing Ukraine and the United States nowadays. I mean a very controversial issue regarding the monuments to the Confederate Army generals, which causes serious social indignation and divides the American citizens into two groups: supporters who consider them as part of their history and opponents who emphasize that the monument to General Robert Lee and others are symbols of the race and social inequality, discrimination and, therefore, should be demolished. A similar situation occurs in Ukraine, it concerns the numerous monuments to the Soviet Union political leaders and military generals who were involved in the capture and enslavement of Ukraine, the repression of the Ukrainian people and the organization of Holodomor of 1932-1933.

These complicated situations clearly show us the close connection between history (its various versions) and the formation of our national, cultural and political identity. Thus, cultural and religious differences of various groups of the population and conflictual issues of the past - all this requires constant rethinking from the philosophy of history. This is extremely important for Ukraine as well as for the rest of the world.

I formulate the notion of narrative tolerance as the basic structure of cultural tolerance and civil society. Narrative tolerance as the basic structure of cultural tolerance has an extensive foundational importance for supporting and developing the concept of modern democratic civil society in the information-oriented globalizing world. Manipulating knowledge of the past and historical consciousness is a real threat to the future of the modern world, since it prevents the existence of a free peaceful society.

It is commonly known that fundamental principles of a democratic rule-of-law state are guaranteed by the force of law. In this context it is of crucial importance to analyze if the narrative theory of historical knowledge can also be a ground for the development of democracy and sociocultural (historical and religious) reconciliation. I am convinced that the modern analytic narrative philosophy of history possesses extraordinary methodological possibilities for successful resolution and prevention of protracted political and sociocultural conflicts, as it is capable of providing us with a whole system of effective conceptual tools for working with historical information in the conditions of modern hybrid wars.

The notion of narrative tolerance is one of such conceptual methodological tools. In my opinion,

\footnotetext{
* Corresponding author: elenmishalova@gmail.com
} 
narrative tolerance is the basic structure of cultural tolerance and civil society. Considered as a principle, narrative tolerance is a strategy for conducting historical research which presupposes two imperative steps: first, the refusal to impose its own national historical narrative on other countries and, secondly, the gradual renunciation of the national narrative and the replacement of it with a regional one or transnational one or a narrative of cultural convergence (for example, interpretation of the Ukrainian history as part of Eastern Europe, the united Europe or the Western democratic world). Considered as a framework, narrative tolerance is a way of writing a historical narrative, which in principle supposes at least two points of view on a particular sequence of historical events. It also presupposes avoiding the following expressions: "old enemy", "endless enmity", "glorious victory," etc. in the practice of historical writing, as they act as triggers to restore past conflicts, adjusting to hostility and militancy $[1$, p. 52$]$. While the modern world is extremely in need of a willingness to understand "the other", openness to dialogue and compromise, the spirit of solidarity.

\section{The role of narrative tolerance in history studying}

The contemporary narrative theory of historical knowledge arose out of fruitful searches, heated debates and even disputes between leading American philosophers of history. In 1965 Arthur Danto published his important book Analytical philosophy of history which summarized a number of still relevant problem issues and contradictions of historical knowledge that can be called "paradoxes of historical knowledge". The most famous of them, for example, are the statement about the impossibility of an uncontroversial and complete historical description, because any description of the past is essentially incomplete, and the paradox of the Ideal Chronicle that can only be an invention or an abstraction. "It is not even an ideal for history to achieve, and that in the nature of the case historians are obliged to aim, not at reproduction but at a kind of organization of the past. ... We cannot conceive of history without organizational schemes, nor of historically organizing schemes apart from specific human interests. ... The difference between history and science is not that history does and science does not employ organizing schemes which go beyond what is given. Both do. The difference has to do with the kind of organizing schemes employed by each" [2, p. 111].

Danto emphasizes that historians use narratives. A narrative as itself is a way of organizing things which describes and explains at the same time. Therefore, a narrative "goes beyond" what is given and involves historians in something one might call "giving an interpretation". This shows us that according to Danto, the maximally detailed account - an ideal duplicate of history-as-actuality - would not be a narrative $[3$, p. 136 , 138]. To tell a story means to exclude some events, a story must leave some things out. That is why any narrative is a structure imposed upon events, grouping some of them together with others and ruling some of them out as lacking relevance [3, p. 20, 132]. "Accounts ... must by their nature leave things out, and in history as elsewhere it is the mark of someone capable of organizing a subject that he knows what to exclude, and is able to assert that some things are more important than others" [2, p. 131]

Danto maintains that our method of organizing past happenings changes, that is, the historian selects various events and constructs his narrative in the other way. This organization will be influenced by what is revealed in retrospect about what has happened. The same event may be a part of unlimited number of historical narratives [3, p. 162]. The reason is that we do not explain events as themselves, but the one that are given specific retrospective descriptions. The choice of description is important in equal measure in both history and science [3, p. 237].

Here we come across another Danto's paradox of historical knowledge: a historical fact is an event under a description. The key structure element for providing such a description is the construction of narrative sentences. Danto proposes to consider narrative sentences as the most distinctive feature of historical knowledge. A narrative sentence refers to at least two time-separated events but it only describes the earliest event to which it refers. He adds further that it logically requires, if it is to be true, the occurrence of both events $[3$, p. 139, 160].

Narrative sentences express our temporal perception of the world. In this context, we should elucidate one more feature of history that is usually underestimated. Historians have a unique privilege of seeing actions in temporal perspective. This means that historians have an advantage which the actor or his contemporaries could not have had in principle. According to Danto, it would be incorrect to complain that we, being at a temporal remove from the actions which concern us as historians, cannot know them in the way in which witnesses might have. "For the whole point of history is not to know actions as witnesses might, but as historians do, in connection with later events and as parts of temporal wholes. To wish away this singular advantage would be silly, and historically disastrous, as well as unfulfillable. It would, in analogy to Plato's image, be a wish to reenter the cave where the future is still opaque. Men would give a great deal to be able to see their actions through the eyes of historians to come" [2, p. 183].

One of the most interesting Danto's conclusions is that we do not see our own actions, at the time we perform them, as having the significance we will later attach to them in the light of further events to which they are to be related. But this turns out to be a general rule for the historical organization of events - they are continually being re-described and their significance reevaluated in the light of later information. And because historians have this information, historians can say things that witnesses and contemporaries could not justifiably have said [3, p. 20]. In this regard, Lidia Goehr remarks that although like present historians, future historians may elicit from a past event a significance of which past historians were not and could not have been aware, no claim by present historians 
should be made as if they were speaking on behalf of future historians as well. Taking into account Danto's idea of incompleteness of the past, she says about narratival openness which means that rather than being content with the material at hand, historians must wait to see how future events in the world will change their contemporary narratives of the past $[4$, p. 7,28$]$.

Danto also argues that the unobservability of the object of study, which until now is considered as the essential weak point in history, is a general feature of scientific research in all advanced sciences. The scientist, just like the historian, very often does not have access to a direct observation of the subject of his study, for example, it concerns electrons or genes. "It is perhaps a logical truth that we cannot observe the past, and merely a matter of contingent fact that we cannot observe electrons or genes. But that the grounds should be logical in the one case and factual in the other does not entail any difference in current practice. There may be branches of science in which the subject-matter is observable: certain parts of chemistry, of zoology, and geology, for instance, come to mind. But these are apt to be very elementary sciences in contrast with, say, atomic physics, and the fact that the most highly developed sciences are concern specifically with unobservable shows, I think, that the unobservability of subject-matter is not an overwhelming disadvantage for science, or that access to subject-matter is an overwhelming advantage" [2, p. 95]. So, dealing with unobservable objects, he is forced to develop theories and some conceptual tools. This circumstance does not pose any special problems for the history, moreover, precisely because we do not have a direct access to the past, there is a history as a science [2, p. 95].

This idea about the narrative as a sort of organizing theory was taken up by Hayden White. In his seminal work Metahistory: The Historical Imagination in the Nineteenth-Century Europe he stresses that the historical narrative is a verbal structure in the form of a narrative prose discourse which plays role of a sign (a model) of past events and processes in the interest of "explaining what they were by representing them" [5, p. 2]. Historical texts (narratives) are all what historians can study with the direct observation. This puts White close to the further deep analysis of the structure of the historical narrative. He proposes to view the historical narrative as a puzzle consisting of facts united through narrativizing strategies. These strategies White understands as having distinct parts. There is a formal argumentation, a plot construction and an explanation by means of ideological implication. Each of them presupposes four possible variations. As a result, we actually have twelve categories of historical consciousness [5, p. 7]. A specific combination of them forms one or another type of historical narrative. Consequently, historical knowledge is the second-order knowledge, it is based on hypothetical constructions of possible objects of research that require interpretation by means of narrative forms.

It should be stressed that White was the first one who clearly realized the incredible danger of such a situation and the consequences that can result from the manipulations with historical information and consciousness in general, especially in the era of the information revolution.

At the same time, White makes a clear division between the event (the state of affairs happened in the particular time and space) and the fact (the statement about this state of affairs). Events occur and more or less adequately reflected in historical texts, facts are conceptually constructed in the thought and/or figuratively in the imagination, that is, exist only in the thought, language and discourse. In The Content of the Form: Narrative Discourse and Historical Representation White adds that these events are real not because they occurred but because they were remembered and are capable of finding a place in a chronologically ordered sequence. In order to be qualified as historical, an event must be susceptible to at least two narrations of its occurrence. Unless at least two versions of the same set of events can be imagined, there is no reason for a historian to take upon himself the authority of giving the true account of what really happened. The authority of the historical narrative is the authority of reality itself. The history, then, sums up White, belongs to the category of what can be called "the discourse of the real" [6, p. 20].

These main ideas of Hayden White caused a lively discussion in which (directly or indirectly) many distinguished scholars from all over the world took part, and this discussion is still going on. White's idea of explanatory strategies aroused a general interest because of its deep connection to some fundamental philosophical concepts, above all the concepts of truth and objectivity of historical knowledge.

Following the constructivist position of White, Leon Goldstein in his famous Historical Knowing emphasizes that there are two realities of the past: the real past which exists outside the totality of historical texts and direct experience of historians and the historical past (the totality of historical texts or narratives) which is created by historians [7, p. 136]. He also insists that the historical fact is not found in the past because a fact is a statement about the past formulated by the historian on the basis of his research. "Historical facts are the products, or outcome, of historical research. ... We have simply no approach to the human past other than by means of historical research" [7, p. 89]. As well as Thomas Kuhn, Hilary Putnam and Karl Popper, Goldstein underlines the role of prior theoretical beliefs. The historian's description is true because it is reasonable to believe that some part of the past had such characteristics, and not because it corresponds to an actual event as a witness may have observed it [7, p. 211], but it does not mean the subjectivity of historians as historians constitute the historical past (this is the core point of their work). Historical knowledge, Goldstein emphasizes, is relative to the discipline of history in the same way that any sort of knowledge is relative to the disciplined way in which it is produced. According to the methodological view, historical objectivity is an intersubjective agreement between historians [7, p. 213]. 
It is important to note that White, using Michael Oakeshott's distinction between "the historical past" and "the practical past", demonstrates that it is very useful for distinguishing between modern professional historians' approaches to the study of the past and the ways in which lay persons (not historians) and practitioners of other disciplines call on, recall or seek to use "the past" with a variety of purposes, for instance, as a basis for all kinds of judgments and decisions in daily life. The kinds of purposes is the key difference between the historical past and the practical past. The historical past is that past which can be studied scientifically, disinterestedly, as an end in itself and for "its own sake". It is a past constructed by historians, its authenticity (but not its reality) is guaranteed by other professional historians. The practical past is made up of all those memories, illusions, bits of vagrant information, attitudes and values which the individual or the group summons up as best they can do to justify, dignify or excuse for actions to be taken in the prosecution of a life project. The practical past is a version of the past that most of us keep in mind and draw on in the performing to our daily task where we compelled to judge situations, make decisions and solve problems [8, p. 16]. White stresses that these two kinds of past are rather more ideal types than descriptions of actual points of view or ideologies. It becomes clear especially if we recall the fact that professional historiography was set up in the universities (in the early nineteenth century) to serve the interests of the nation-state, to help in the work of creating national identities, and was used in the training of educators, politicians, imperial administrators and both political and religious ideologues in manifestly practical ways [8, p. 17]. As a result White concludes that the practical past needs to be the subject of consideration of the philosophy of history which could bring the order and reason more than the historical past [8, p. 18]. One cannot disagree with this White's position, but nevertheless, it should be remarked that the analytic narrative philosophy of history (more particularly, a notion of narrative tolerance) can successfully be involved in work on both the professional historiography and the ordinary historical information.

Based on works by Danto, White and Goldstein, Paul Roth develops an interesting and fruitful irrealist approach (an irrealist account of history). According to his The Pasts, we can speak about a plurality of pasts which exists because constituting a past always depends to some degree on socially mediated negotiations of what could or could not happened. Roth argues for pasts as constructed (not found) and stresses the priority of classification over perception in the order to understand and verify historical knowledge [9, p. 339]. He stresses that only descriptions create a past in which human actions have meaning. Of course, what has been done cannot be undone. But "that will turn out to depend on what one takes a "doing" to be. If what happens in the world is at least in part a function of human actions, and if what actions are Goodmanian kinds, that is, exemplifications of ways a given community descriptively collates behaviors in particular ways, then when new description, new ways of collating physical doings, become available, this changes what actions happened" [9, p. 333].

Roth notes that nothing a priori anchors practices of classification, therefore, no sense can be attached to claims that some single structure must or does determine what events take place in human history. Given alternative modes for structuring what happens, changes in description can alter relations among events imputed to a past, and so how a past thus structured impacts what becomes possible going forward. "A plurality of pasts results because constituting a past depends to some degree on socially mediated negotiations of a fit between descriptions and experience. Even what we take to mark what can change and what cannot itself depends on the descriptions deployed. Unless for reasons now unknown there ceases to be a possibility of descriptive change or reclassification, human histories will continue to reveal a multiplicity of pasts" [9, p. 339].

There is no principal distinction between empirical knowledge in general and historical knowledge at the most general epistemological and metaphysical level. This point suggests that the forms of inference (inductive, deductive and abductive) arise for all cases of knowledge. Such things as events, facts, actions, kinds exist and have explanation only in a theory. The temporal distance may accentuate some problems of making sense of others and what they did, but the problems posed turn out not to be unique at all [9, p. 336].

So, the narrative theory of historical knowledge can provide us with a whole system of methodological tools to study conflicting historical past in order to establish inclusive unbiased vision of history. Narrative tolerance has an extraordinary significance in constituting such an unbiased tolerant paradigm of history.

\section{The role of narrative tolerance in history teaching}

The investigation of narrative tolerance gains extra significance in view of developing modern information civil society in the present-day world. To build it we need tolerant historical thinking as well as critical thinking.

According to Gabrielle Spiegel, the greatest issue facing the practice of history today is to understand its relationship to ethical goals $[10$, p. 505]. Its means an ethical response to the catastrophes of the last century and, in a more general sense, a turn from epistemological to ethical commitments in the study of the past, creating a place and an opportunity for a new historical ethics. Spiegel underlines that this ethical approach to history cannot and should not mean the abandonment of the search for evidence, the responsibility to seek to "get it right" in our investigation of the past, or the insistence on a critical approach to knowledge in all its manifest forms as the fundamental practice of the historian $[11$, p. 177].

In the middle of the last century Karl Popper in his famous work The Open Society and its Enemies drew attention to our ordinary mode of history writing as 
mainly political history. From his point of view, there is no history of mankind, there are only many histories of all kinds of aspects of human life. And one of these is the history of political power. This is elevated into the history of the world. But this, as Popper stresses, is an offence against every decent conception of mankind. It is hardly better than to treat the history of embezzlement or of robbery or of poisoning as the history of mankind. "For the history of power politics is nothing but the history of international crime and mass murder (including, it is true, some of the attempts to suppress them)" [12, p. 257]. Popper rightly accentuates the fact that this history is taught in schools, and many of the greatest criminals are presented as heroes. The main reason of such a situation is that many historians as a rule wrote their texts under the supervision of the authority ("the generals and the dictators") [12, p. 257].

That is why Bertrand Russell especially defeats a feeling of intellectual independence of teachers in his essay The function of a Teacher. It is essential to the proper fulfillment of the teacher's functions, since it is his business to instill what he can of knowledge and reasonableness into the process of forming public opinion [13, p. 113].

Russell puts the point that the thing that a teacher should endeavor above all to produce in his students if democracy is to survive, is the kind of tolerance that springs from an endeavor to understand those who are different from us. Russell believes that it is a natural human impulse to view with horror and disgust all manners and customs different from those to which we are used. And those who have never travelled either physically or mentally find it difficult to tolerate the queer ways and outlandish beliefs of other nations and other times. This kind of ignorant intolerance is the antithesis of a civilized outlook, and is one of the gravest dangers to which our overcrowded world is exposed. The educational system ought to be designed to correct it, but much too little is done in this direction at present. In every country nationalistic feeling is encouraged, and school children are taught in such a manner that the inhabitants of other countries are morally and intellectually inferior to those of the country in which the school children happen to reside and they are absolutely ready to believe it $[13$, p. 121].

Russell stresses that in every country history is so taught as to magnify that country: children learn to believe that their own country has always been in the right and almost always victorious, that it has produced almost all the great men, and that it is in all respects superior to all other countries. He illustrates this point with a simple example: the facts about the battle of Waterloo which are known in great detail and with minute accuracy. But the facts as taught in schools will be widely different in England, France, and Germany. He notes in Education that "the ordinary English boy imagines that the Prussians played hardly any part; the ordinary German boy imagines that Wellington was practically defeated when the day was retrieved by Blucher's gallantry. If the facts were taught accurately in both countries, national pride would not be fostered to the same extent, neither nation would feel so certain of victory in the event of war, and the willingness to fight would be diminished. It is this result which has to be prevented. Every state wishes to promote national pride, and is conscious that this cannot be done by unbiased history. The defenseless children are taught by distortion and suppressions and suggestions" [14, p. 382].

Russell adds further that there is a widespread belief that nations are made strong by uniformity of opinion and by the suppression of liberty. But nations have been brought to ruin much more often by insistence upon a narrow-minded doctrinal uniformity than by free discussion and the toleration of divergent opinions. "It is obvious that organized party spirit is one of the greatest dangers of our time. In the form of nationalism it leads to wars between nations, and in other forms it leads to civil wars. It should be the business of teachers to stand outside the strife of parties and endeavor to instill into young the habit of impartial inquiry, leading them to judge issues on their merits. ... The function of the teacher, however, is not merely to mitigate the heat of current controversies. He has more positive task to perform. Teachers are more than any other class the guardians of civilization" [13, p. 117].

The false ideas as to the history of the world which are taught in various countries are of a kind which encourages strife and serves to keep a bigoted nationalism alive. If good relations between States were desired, one of the first steps ought to be to submit all teaching of history to an international commission, which should produce neutral textbooks free from the patriotic bias which is now demanded everywhere [14, p. 382].

This circumstance requires narrative tolerance which rests upon the idea of philosophical pluralism. Advancing the narrative tolerance as well as the narrative theory of history in philosophy of history and social philosophy provides us with effective methodological tools for working with historical information in the conditions of conflicting historical past, divided societies and modern hybrid wars.

Eva Domanska finds Ethics as the practice of care emphasizing that Ethics is of key importance for historiographical criticism and is not understood as a set of abstract rules but as the product of the student's own everyday experience. Historiographical criticism combines a close reading of texts with ethical reflection which reaches beyond the text [15, p. 200].

We should remember here an interesting thesis of Russell's: "I believe that the control of our acts by our intelligence is ultimately what is of most importance, and what alone will make social life remain possible as science increases the means at our disposal for injuring each other. Education, the press, politics, religion - in a world, all the great forces in the world - are at present on the side of irrationality; they are in the hands of men who flatter King Demos in order to lead him astray. The remedy does not lie in anything heroically cataclysmic, but in the efforts of individuals toward a more sane and balanced view of our relations to our neighbors and to the world. It is to intelligence, increasingly wide-spread, that we must for the solution of the ills from which our world is suffering" [16, p. 39]. 
Domanska emphasizes that we must address the question of the limits or the frameworks of interpretation, the question of the "ethics of analysis". The idea of multiple meanings of texts and of the impossibility of a definitive interpretation does not mean that every interpretation is equally acceptable. The student's decision to use a given theory, interpretative category, or way of thinking is related to his/her worldview, existential situation, and the choice of intellectual tradition that corresponds to his/her view of the world and the human being. On the deep level, therefore, the choice of method is an existential and ethical choice. At the same time, Domanska notes that the problem of the "ethics of analysis" and the limits of representation is an aporia, touching upon the dilemma of being situated between the freedom of choice and the abstract ideals or accepted values which impose constraints on that freedom [15, p. 201].

White develops a thesis that every historical narrative has as its latent or manifest purpose the desire to moralize the events of which it treats. He suggests that narrativity certainly is related (if not a function of) the impulse to moralize reality, that is, to identify it with the social system that is the source of any morality that we can imagine. White defines the social system as a system of human relationship governed by law, creates the possibility of conceiving the kinds of tension, conflicts, struggles, and their various kinds of resolutions that we are accustomed to find in any representation of reality presenting itself to us as a history [6, p. 14].

As Keith Jenkins shows, history is one of a series of discourse about the world. These discourses do not create the world (that physical stuff on which we apparently live) but they do appropriate it and all the meanings it has. More precisely, history is a discourse about the past but categorically different from the past. History and the past are not stitched into each other so that only one historical reading of the past is absolutely necessary. The past and history float free of each other, they are ages and miles apart. For the same object of enquiry can be read differently by different discursive practices [17, p. 7]. "No discourse - and therefore no contribution to, and/or comment on, aspects of an existing discourse - is of 'a natural kind'. You cannot find a historical or geographical or scientific or literary discourse just out there, just growing wild. Discourses are cultural, cultivated, fabricated and thus ultimately arbitrary, ways of caving up what comes to constitute their "field" [18, p. 15].

That is why it is crucially important to develop and promote the principle of narrative tolerance in history teaching. Because there can be no history of the past as "it actually happened". There can only be historical interpretations, and none of them final; and every generation has a right to frame its own. But not only has it a right to frame its own interpretations, but it also has a kind of obligation to do so [12, p. 255].

I want to sum up this essay with White's vision about the role of History (as a science) and historians in the present world. History can provide a ground upon which we can seek that "impossible transparency" demanded for the distracted humanity of our time. Only a chaste historical consciousness can truly challenge the world anew every second, for only history mediates between what is and what men think ought to be with truly humanizing effect [19, p. 134]. "The burden of the historian in our time is to re-establish the dignity of historical studies on a basis that will make them consonant with the aims and purposes of the intellectual community at large, that is, transform historical studies in such a way as to allow the historian to participate positively in the liberation of the present from the burden of history" [19, p. 124].

\section{References}

1. O. Mishalova, Naratyvna tolerantnist: vykhid iz labiryntu natsionalnykh istorychnykh naratyviv (Narrative Tolerance: Overcoming the Maze of National Historical Narratives). Actual Problem of Mind. 20, 46-71 (2019)

2. A. Danto, Narration and Knowledge (Columbia University Press, New York, 2007)

3. A. Danto, Analiticheskaya filosofiya istorii (Analytical Philosophy of History). (Ideya-Press, Moscow, 2002)

4. L. Goehr, Afterwords: an introduction to Arthur Danto's philosophies of history and art. History and Theory 46, 1-28 (2007)

5. H. White, Metahistory: The Historical Imagination in the Nineteenth-Century Europe (The Johns Hopkins University Press, Baltimore and London, 1975)

6. H. White, The Content of the Form: Narrative Discourse and Historical Representation (The Johns Hopkins University Press, Baltimore and London, 1987)

7. L. Goldstein, Historical Knowing (University of Texas Press, Austin and London, 1976)

8. H. White, The practical past. Historein 10, 10-19 (2010)

9. P.A. Roth, The Pasts. History and Theory 51(3), 313-339 (2012)

10. G.M. Spiegel, Above, about and beyond the writing of history: a retrospective view of Hayden White's Metahistory on the $40^{\text {th }}$ anniversary of its publication. Rethinking History 17(4), 492-508 (2013)

11. G.M. Spiegel, The future of the past: History, memory and the ethical imperatives of writing history. Journal of the Philosophy of History 8 , 149179 (2014)

12. K. Popper, The Open Society and its Enemies, Volume II. The High Tide of Prophecy: Hegel, Marx and the Aftermath (George Routledge and Sons, London, 1947)

13. B. Russell, Unpopular Essays (Simon and Schuster, Wolf H. Book Manufacturing Company, New York, 1950) 
14. R.E. Egner, L.E. Denonn (ed.), The Basic Writings of Bertrand Russell (Routledge Classics, London and New York, 2009)

15. E. Domanska, in Manifestos for History, ed. by K. Jenkin, S. Morgan, A. Munslow (Taylor and Francis Group, London and New York, 2007), pp. 197-203

16. B. Russell, Sceptical Essays (Routledge Classics, London and New York, 2004)

17. K. Jenkins, Re-thinking History (Routledge: Taylor and Francis, London and New York, 2004)

18. K. Jenkins, On “What is History? ': From Carr and Elton to Rorty and White (Routledge: Taylor and Francis, London and New York, 2005)

19. H. White, The Burden of History. History and Theory 5(2), 111-134 (1966) 